\title{
The predictors of COVID-19 anxiety and helping behaviour during the pandemic: An investigation within the framework of individual and national level resources
}

\author{
Özge Ünal ${ }^{1}$ (D) $\cdot$ Merve Cesur-Atintaşs $^{2}$ (D) • Elvan Kiremitçi-Canıöz ${ }^{3}$ (D) Hilal Kaya $^{4}$ (D) Yağmur Yağmurcu $^{5}$ (D)
}

Accepted: 13 April 2021 / Published online: 17 April 2021

(C) The Author(s), under exclusive licence to Springer Science+Business Media, LLC, part of Springer Nature 2021

\begin{abstract}
Governments have developed different policies against the COVID-19 outbreak. Therefore, individuals' political trust, as well as their coping styles, seems to play a role in society's reactions to this process. This study aims to examine the determinants of both the COVID-19 anxiety and the helping behavior during the pandemic within the framework of political trust and coping styles. The sample consists of 529 participants (340 females 189 males) from different cities in Turkey between the ages of 18-68. Coping Style Scale, Political Trust Inventory, Flourishing Scale and questionnaires measuring helping behaviour, perceived risk and COVID-19-related anxiety were used for data collection. The results showed that self-confident coping style and competence evaluations towards politicians predicted COVID-19 anxiety through perceived risk, while various coping styles and positive expectations towards politicians predicted helping behaviour through psychological well-being. This research contributes to literature by revealing the importance of individual and national level resources coping with COVID-19 crisis.
\end{abstract}

Keywords Anxiety $\cdot$ COVID-19 $\cdot$ Helping $\cdot$ Political trust $\cdot$ Psychological well-being

\section{Introduction}

Since the World Health Organisation (World Health Organization (WHO, 2020) declared the COVID-19 outbreak to be a pandemic, governments have attempted to manage this health crisis with different strategies. Some of them announced lockdowns in several risky areas and sanctions to the violators while others encouraged just voluntary

Özge Ünal

ozgeunal@mersin.edu.tr

Merve Cesur-Atintaș

mcesur@ankara.edu.tr

Hilal Kaya

hkaya@ankara.edu.tr

Yağmur Yağmurcu

yagmuryagmurcu@kilis.edu.tr

Department of Psychology, Mersin University, Mersin, Turkey

2 Department of Psychology, Ankara University, Ankara, Turkey

3 Department of Psychology, Balıkesir University, Balıkesir, Turkey

4 Institute of Forensic Sciences, Ankara University, Ankara, Turkey

5 Department of Psychology, Kilis 7 Aralık University, Kilis, Turkey adherence to some rules in order to curb the pandemic. In the days following the declaration of the pandemic, strict restrictions were not applied in Turkey. Government called on the citizens to stay at home and did not take a lockdown decision outside the curfew imposed at weekends. However, all businesses and schools were temporarily closed and distance education was started. Intercity travel was restricted and all airlines stopped the flights. Flexible and remote working in public institutions started. This whole process continued between March 11 and June 1.

The outbreak has had several negative outcomes in societies and a lot of people experienced high levels of stress. Because of the economic crisis after the terms of lockdown, some citizens have lost their jobs. Therefore, citizens have tried to cope with not only health-related concerns but also economic concerns. Many studies from different countries have demonstrated that the outbreak and lockdown cause high levels of stress in individuals (i.e. Horesh et al., 2020). The stressful experience of coping with the coronavirus outbreak and the preventions taken by governments (Brooks et al., 2020) appear to have effects on the well-being of individuals (Cabarkapa et al., 2020). During the COVID-19 pandemic, daily life for an adult consists of following up the social media and news to obtain information about COVID-19, homeworking or going to work in a process where many people 
working at home, experiencing social isolation, taking care of their children, if any, and helping them with home-schooling. According to several studies, all these are related to decrease in well-being (Allcott et al., 2020; Lades et al., 2020). However, although the new conditions of this challenging process seem to have negative effects on individuals' wellbeing, it cannot be denied that people's functionality levels and the coping potential they have are different from each other when entering this crisis. At this point, it is thought that individuals' coping strategies would be a key for inferring how they have been affected from the crisis and to what extent they have experienced anxiety during this whole process.

Since this outbreak is defined as a global crisis and governments have engaged in the control practices to decrease spreading, political trust that people have had before this crisis should be taken into account in addition to these individual characteristics in coping with stress. It was shown that political trust of citizens positively predicted their individual well-being during the COVID-19 pandemic (Paolini et al., 2020). In addition, according to a recent study (Mana \& Sagy, 2020) both personal level resources like social support and the sense of coherence (i.e. evaluating the world as meaningful) and national level resources like trust in national institutions and the sense of national coherence (i.e. evaluating the national group to which one belongs as meaningful) predicted mental health during COVID-19 outbreak. In the current study among the resources which people benefit with, personal level resource was defined as styles of coping with stress and the national level resource was defined as political trust. In this study, ways of coping with stress were classified into 5 styles based on Șahin and Durak's classification (Hisli-Șahin \& Durak, 1995): self-confident style, optimistic style, seeking of social support, hopeless style and submissive style. On the other hand, political trust includes three components based on a study conducted in Turkey (Çoymak, 2009): the satisfaction with the politicians' actions and the belief that they are concerned with the public's interest (expectation), the evaluations regarding the politicians to be honest and trustful (honesty) and the evaluations regarding the politicians to be competent and capable for the effective decisions (competency). Social trust, political trust and perceived risk are substantial factors explaining the individuals' reactions to stress resources like natural disasters and outbreaks affecting the whole society (Bronfman et al., 2016). There is evidence that the information provided by governments can reduce the perceived risk, and anxiety in epidemics affecting public health (Balaratnasingam \& Janca, 2006; Philip \& Cherian, 2020). In addition, recent studies have shown that COVID-19 risk perception plays an important role in preventive health behavior (Alper et al., 2020; Marinthe et al., 2020). Taken together, in the current study it is thought that political trust could predict individuals' anxiety through their risk perception. The first aim of this study is to determine the predictors of coronavirus-related anxiety within the scope of coping skills (individual level resource) and political trust (national level resource).
On the other hand, altruistic tendencies of individuals increase after the crises affecting large groups in societies (Morgeson et al., 2015; Silva et al., 2009; Stanko et al., 2015). Likewise, during this challenging time, emphasis on solidarity and altruism seems to have increased. Governments have encouraged citizens, even if they are not in the high-risk group for the disease, to adhere to the rules such as physical distancing and wearing masks for protecting others from being infected with the virus. Social workers working with elderly have encouraged people to provide psychological support to elderly people in order to promote their health behavior and enhance their mood. People have been invited to provide food to street animals. Considering all, this study aims to explore the predictors of helping others to cope with the negative effects of this crisis. In challenging times full of uncertainties, creating a shared group identity with the sense of "we are in this together" can enable governments to coordinate their citizens for shared goals (Van Bavel et al., 2020). Creating a shared social identity while solving problems may encourage citizens to cooperate, increase their political trust (Reicher et al., 2005) and support their sense of selfefficacy and hope (Fransen et al., 2015). This positive effect on the psychological health of individuals could intensify their helping behavior. Several studies (Forgas et al., 2008; Martela \& Ryan, 2016; Piliavin, 2003; Salovey et al., 1991; Schwartz et al., 2009) have shown the association between individuals' helping behavior and their psychological well-being. Since the individuals become more sensitive to others' needs when they feel better in their life (Lyubomirsky \& Dickerhoof, 2011), psychological well-being of individuals could trigger their helping behaviors during the outbreak. Consequently, it is hypothesized that the personal level resources (coping styles) and national level resources (political trust) individuals have would predict individuals' psychological well-being, and the psychological well-being, in turn; predict their helping behavior during the coronavirus pandemic. Therefore the second aim of this study is to investigate the paths of coping styles and political trust to psychological well-being and helping behavior.

In short, the current study aims to examine the factors that determine both the COVID-19-related anxiety and the helping behavior during this crisis in the frame of political trust and coping styles (See Fig. 1.)

\section{Method}

\section{Participants}

Participants were reached via an online survey. The sample group of the present study consisted of 529 participants from different cities in Turkey. Among participants, 340 (64.3\%) of whom were females and 189 (35.7\%) of whom were males. 
Fig. 1 Hypothesized model for predicting the COVID-19-related anxiety and helping behavior

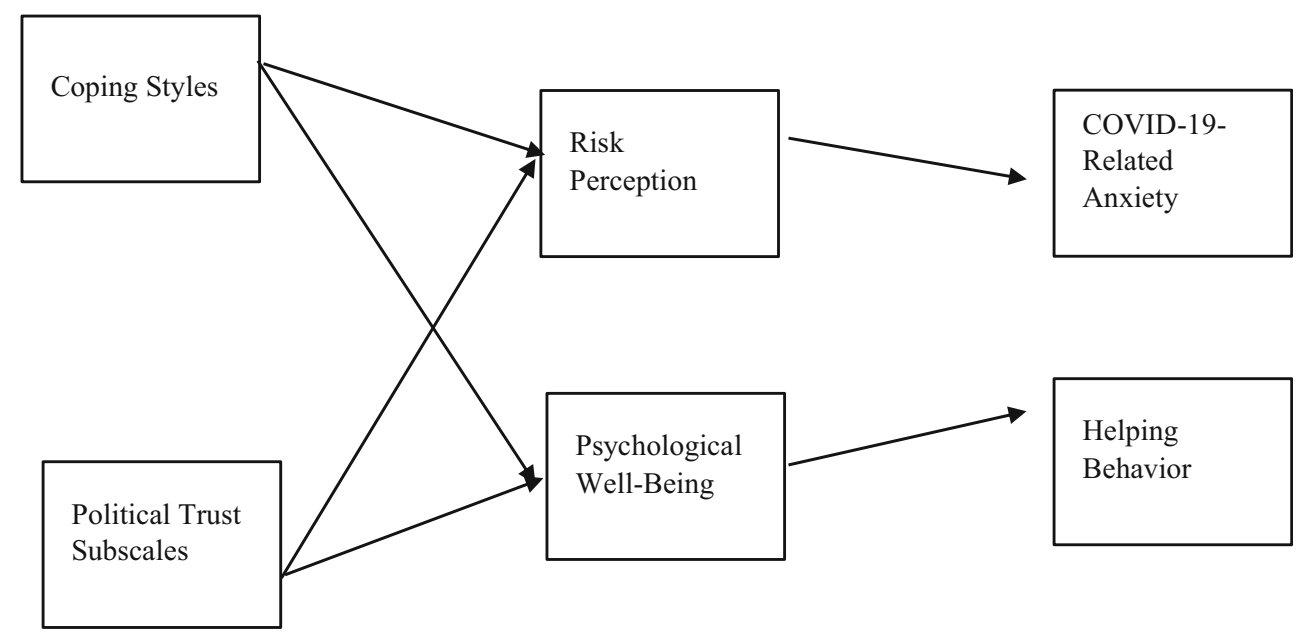

The ages of participants ranged between 18 and $68(\mathrm{M}=$ $32.66, \mathrm{SD}=10.49)$. In terms of the education level, it was seen that $0.4 \%$ of the participants had primary school degrees, $29.6 \%$ had high school degrees, $50.4 \%$ had university degrees, and $19.5 \%$ had postgraduate degrees.

\section{Measures}

Demographic Information To determine socio-demographic characteristics of the participants, researchers have prepared a socio-demographic information form which includes questions about gender, age, education level, income level etc.

COVID-19-Related Risk Perception Participants' perceived risk of COVID-19 was measured with a single item ("To what extent do you believe you are at risk of being diagnosed with COVID-19?") on a 7 point scale ranging from 1 (low risk) to 7 (high risk).

COVID-19-Related Anxiety Anxiety levels of participants were measured by a single item ("How anxious have you been related to COVID-19 lately?") on a 7 point scale ranging from 1 (too little) to 7 (too much).

Political Trust It was measured using Political Trust Inventory, which aims to determine people's political trust levels. It is rated on a 7-point Likert type scale and consists of 19 items. The scale, which was developed by Çoymak (2009), has three subscales: "fiduciary expectation", "honesty" and "competence". In the current study the original instruction of the scale "Evaluate each of the following statements considering the members of parliament" has been changed with "Evaluate each of the following statements considering the politicians who have an impact on Turkey's course recently". In the original study, the Cronbach's alpha internal consistency coefficients were calculated as .88 for fiduciary expectation, .88 for honesty, and .72 for competence. In the current study internal consistencies were found .95 for expectation, .90 for honesty, and .83 for competence.

Coping Style Participants' coping styles were measured using Coping Style Scale which was developed by Hisli-Şahin and Durak (1995), on the basis of Folkman and Lazarus's (1980) Ways of Coping Inventory. This scale aims to measure coping styles with different stressors such as loneliness, depression and psychosomatic problems. The four-point Likert-type scale consists of 30 items and five factors: "Optimistic style", "Selfconfident style", "Seeking of social support", "Helpless style" and "Submissive style". The internal consistency coefficients of the factors range between .45 and .80 (Hisli-Şahin \& Durak, 1995). The Cronbach's alpha values of Coping Style Scale factors found in the current study were .80 for optimistic, .87 for self-confident, .62 for social support, .80 for helpless and .60 for submissive approach.

Psychological Well-Being Well-being levels of participants were measured using the Flourishing Scale, developed by Diener et al. (2010) to evaluate human functioning of individuals, such as feeling competent and having positive relationships. The seven-point Likert-type scale consists of 8 items and one factor. High scores indicate the high level of "psychological well-being". In other words, it indicates that the person has many psychological resources and strengths. In the original study, the Cronbach's alpha coefficient was found to be .87 . The scale, which was adapted to Turkish by Telef (2013), is referred to as the "Psychological Well-Being Scale" in Turkish. The Cronbach's alpha coefficient of the Turkish version was .80. In the current study the Cronbach's alpha of the scale was found to be .87 .

Helping Behavior To measure the helping behavior, participants were asked to answer a questionnaire developed by the researchers. All items are about helping-related behaviors in the last two months, such as providing financial support to 
someone in need, feeding the street animals, giving emotional support to someone during the outbreak. The scale consists of 5 items and is rated on a seven-point Likert type scale. The Cronbach's alpha value of the scale was found to be .66 .

\section{Procedure}

The present study was on a voluntary basis and all participants signed the informed consent form. Google Forms was used for data collection. Multiple responses from the same IP address were not allowed. Data collection process, continued during the period of restrictions concerning COVID-19 in Turkey, was completed between May-June 2020. Statistical analyses were carried out via SPSS 20.0 and LISREL 8.51.

\section{Results}

The analyses for descriptive statistics, bivariate correlations and reliability of the scales were conducted with the statistical package of SPSS 20.0. Path models were performed for hypothesis testing by using LISREL 8.51 (Jöreskog \& Sörbom, 1993). The maximum likelihood method was used to test the model fit. In order to evaluate the goodness of the model multiple fit indices were taken into account. The indices used in the present study were Goodness of Fit Index (GFI), Adjusted Goodness of Fit Index (AGFI), Comparative Fit Index (CFI), Root Mean Square Error of Approximation (RMSEA), and the ratio of $\chi^{2} / \mathrm{df}$. GFI, AGFI, and CFI values exceeding .90, RMSEA value below .08 and $\chi^{2} / \mathrm{df}$ value below 3 indicate a good fit to the data.

The aim of the study was to investigate the predictors of COVID-19-related anxiety and helping behavior during coronavirus pandemic. It was hypothesized that both coping styles and political trust dimensions would predict anxiety and helping behavior. It was also hypothesized that risk perception would mediate the relationship of the coping styles and the political trust dimensions with anxiety while psychological well-being would mediate the relationship of coping styles and political trust dimensions with helping behavior. After testing the bivariate correlation between the variables we found several relationships between the predictor variables and the mediator variables of the conceptual model. Optimistic style and self-confident style among the coping styles in addition to competence among political trust dimensions were related to risk perception. On the other hand, all the five coping styles in addition to the expectation dimension of political trust were related to psychological well-being. In addition, according to the bivariate correlation analysis (see Table 1) the hypothesized mediator variables were related to the outcome variables. The correlations were in the directions as expected.
All paths between significantly related variables were tested in the hypothesized model. Then nonsignificant paths were dropped from the model. In addition to the hypothesized regression paths, we identified the correlation of risk perception and psychological well-being in the model. The fit indices of the final model indicated that the model provided an excellent fit to the data $\left(\chi^{2}(19, N=529)=27.07, p=.10, \chi^{2} / \mathrm{df}=1.42\right.$, RMSEA $=.03, \mathrm{CFI}=1.00, \mathrm{GFI}=.99, \mathrm{AGFI}=.97)$. The model accounted for $5 \%$ of risk perception, $6 \%$ of anxiety, $31 \%$ of psychological well-being and $17 \%$ of helping behavior. The results are given in Fig. 2.

Lower self-confident coping style $(\beta=-.19, p<.05)$ and competence $(\beta=-.11, p<.05)$ predicted risk perception. Risk perception $(\beta=.18, p<.05)$, in turn, predicted coronavirus-related anxiety. Risk perception fully mediated the relationships of self-confident coping style and competence with anxiety (indirect effects $=.03, .02 ; \mathrm{t}=3.03,2.21$; $p<.05$, respectively). In addition to these mediated relationships, honesty directly predicted the anxiety $(\beta=-.16, p$ $<.05)$. Higher seeking of social support coping style $(\beta=.17, p<.05)$, higher self-confident coping style $(\beta=.35, p<.05)$, lower helpless coping style $(\beta=-.25, p$ $<.05)$, and higher expectation $(\beta=.09, p<.05)$ predicted psychological well-being. Psychological well-being $(\beta=.39$, $p<.05)$, in turn, predicted helping behavior. Psychological well-being fully mediated the relationship of coping styles and the helping behavior (indirect effects $=.07, .14,-.10$; $\mathrm{t}=4.22,6.41,-5.16 ; \mathrm{p}<.05$, respectively). However, psychological well-being partially mediated the relationship of expectation and helping behavior. (indirect effect $=.04, \mathrm{t}=$ $2.47, \mathrm{p}<.05)$.

\section{Discussion}

The present study aimed to examine the effects of individual (coping styles) and national (political trust) level resources people have during the coronavirus pandemic on risk perception, anxiety, psychological well-being, and helping. For this purpose, a model in which individual and national resources predict anxiety and helping behavior through risk perception and psychological well-being was tested. The findings showed that there were significant mediating effects of risk perception and well-being on experienced anxiety and helping behavior.

The decrease in self-confident coping style, which is considered as an individual level resource in coping with the negative psychological effects of the pandemic, and the decrease in the competence dimension of political trust, which is considered as a national level resource, predicted experienced anxiety through increase in risk perception. Among the styles of coping with stress, self-confident style predicted anxiety through risk perception whereas other coping styles 
Table 1 Bivariate correlations between the variables of the study

\begin{tabular}{|c|c|c|c|c|c|c|c|c|c|c|c|c|}
\hline & 1 & 2 & 3 & 4 & 5 & 6 & 7 & 8 & 9 & 10 & 11 & 12 \\
\hline 1. Risk & - & & & & & & & & & & & \\
\hline 2. Anxiety & $.19 * *$ & - & & & & & & & & & & \\
\hline 3. Social S & .04 & .05 & - & & & & & & & & & \\
\hline 4. Optimistic & $-.17 * *$ & -.06 & .01 & - & & & & & & & & \\
\hline 5. Confident & $-.20 * *$ & -.05 & .08 & $.73 * *$ & - & & & & & & & \\
\hline 6. Helpless & .08 & .02 & -.03 & $-.42 * *$ & $-.44 * *$ & - & & & & & & \\
\hline 7. Submissive & .08 & -.03 & $-.13 * *$ & -.07 & $-.26 * *$ & $.49 * *$ & - & & & & & \\
\hline 8. Honesty & -.06 & $-.18 * *$ & -.02 & $.13^{* *}$ & $.09 *$ & .01 & $.15^{* *}$ & - & & & & \\
\hline 9. Expectation & -.06 & $-.13 * *$ & -.02 & $.16^{* *}$ & .06 & .04 & $.19 * *$ & $.72 * *$ & - & & & \\
\hline 10. Competence & $-.12 * *$ & $-.14 * *$ & -.02 & $.12 * *$ & .07 & .06 & $.17 * *$ & $.81 * *$ & $.80 * *$ & - & & \\
\hline 11. PWB & $-.17 * *$ & -.06 & $.20 * *$ & $.42 * *$ & $.48^{* *}$ & $-.40 * *$ & $-.25 * *$ & .07 & $.10^{*}$ & .08 & - & \\
\hline 12. Helping & .06 & -.03 & $.09 *$ & $.24 * *$ & $.24 * *$ & $-.18 * *$ & -.01 & .07 & $.13 * *$ & .06 & $.40 * *$ & - \\
\hline
\end{tabular}

** $p<.01, * \mathrm{p}<.05$ Note $:$ Risk = Risk perception; Social $\mathrm{S}=$ Seeking of social support coping style; Confident = Self confident coping style; $\mathrm{PWB}=$ Psychological well-being

(optimistic style, seeking of social support, helpless style and submissive style) did not. This finding demonstrates the importance of self-confident coping style in the COVID-19 pandemic, which corresponds to trusting personal skills and competence in the face of problems and displaying a mature attitude in meeting problems. The COVID-19 pandemic has taken humanity into a process full of uncertainty about the future. Considering that this process is beyond the control of

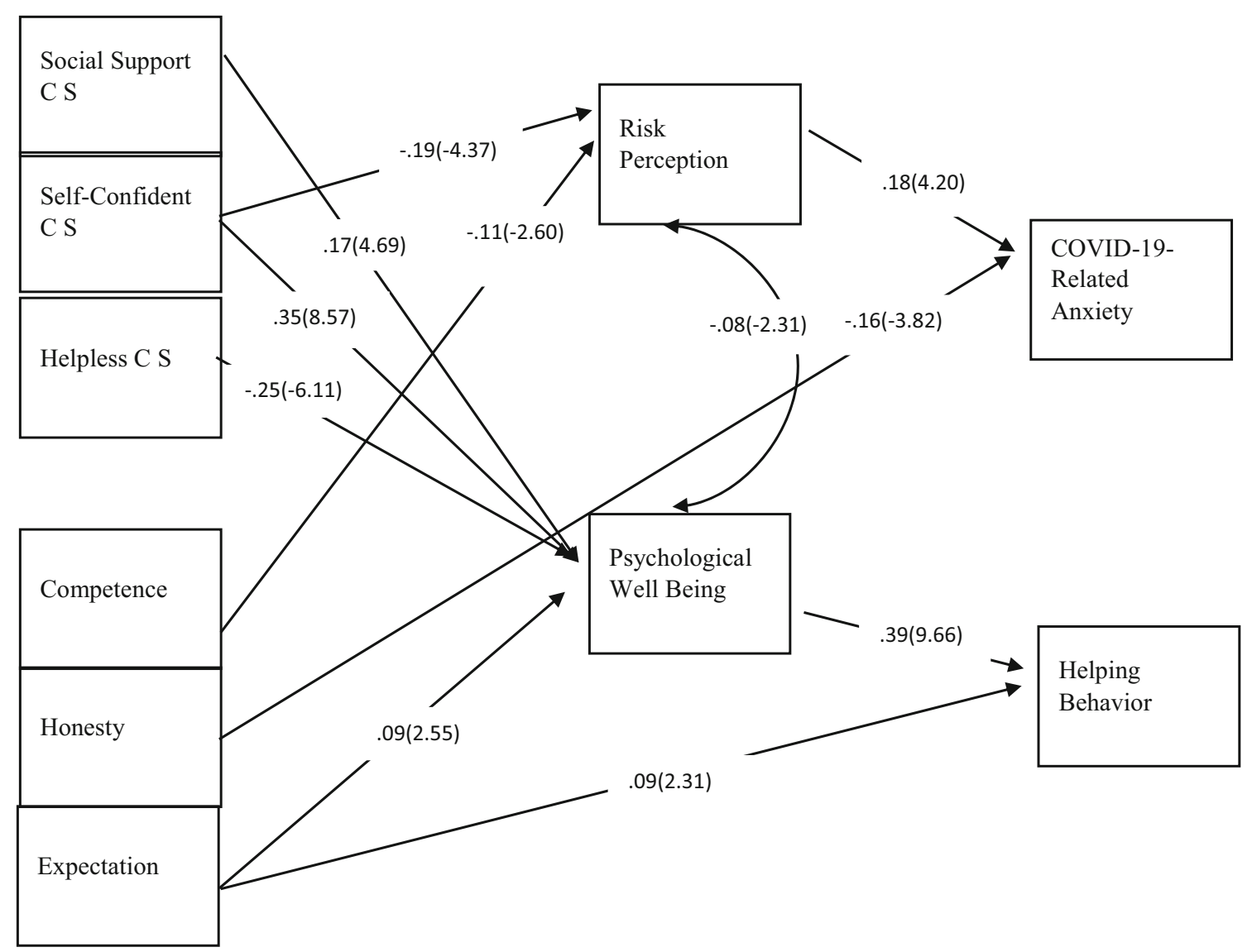

Fig. 2 Results of path model analysis testing direct and indirect effects of coping styles and political trust dimensions on COVID-19-related anxiety and helping behavior. Note: Only statistically significant paths were shown (standardized values). $t$ values were presented in parentheses 
individuals and the whole world has difficulty in controlling it, and this situation is a source of unavoidable stress (Van Bavel et al., 2020), it will not be easy to develop a self-confident or control-oriented approach. Therefore, the perception of this process outside of control, in other words, the inability of individuals to cope with it in a self-confident way, may lead to anxiety about COVID-19 through feeling themselves at risk. It can be said that individuals who rely on their own competencies in coping with problems feel less threatened and experience lower levels of anxiety in this process, where the importance of social distance is emphasized and all life is interrupted. This finding confirms the finding of another study on anxiety related to H1N1 virus (Taha et al., 2014) that controlling uncertainty affects anxiety levels of people. People who know how to cope with the pandemic self-confidently create a new routine for themselves, regain a sense of control over uncertainties, and manage their risk perceptions and thus reduce their anxieties about COVID-19.

Among the dimensions of political trust, which we consider as the national level resource of individuals in dealing with the pandemic, we see that the competence dimension predicts the COVID-19 anxiety through the risk perception. In such crises, individuals expect authorities, those who need to take initiative, to be determined and competent in taking steps towards the situation (Van Bavel et al., 2020). Bronfman et al. (2016) showed that in situations such as natural disasters that people cannot manage individually, trusting the competence of authorities and institutions is associated with a decrease in risk perception. Similar findings were obtained in studies examining the risk perception caused by nuclear power (Pidgeon et al., 2008) and genetically modified foods (Poortinga \& Pidgeon, 2005). According to the findings of the current study, the competency dimension of political trust, which corresponds to "the beliefs that politicians' decision-making ability and the power to achieve effective results are sufficient" is the only dimension that explains anxiety through risk perception. This finding displayed a similar pattern to the relationship between the above-mentioned coping styles, the risk perception and anxiety. Seemingly, individuals need to feel adequate and competent at both the individual level and the national level to calm their anxiety in the COVID-19 pandemic that have occurred suddenly and beyond their control.

Findings showed that among the dimensions of political trust, competence predicted COVID-19 anxiety through the risk perception, while honesty directly predicted anxiety. As described earlier, competence corresponds to the belief that the politicians' actions will be effective, whereas honesty refers to evaluating politicians as reliable and loyal to their words. One can infer from these findings that citizens' risk perceptions depend on the abilities of politicians rather than the honesty of politicians. Considering this crisis is threatening people's lives, it is not surprising that to feel safe, citizens need effective practices to be implemented by the government more than they need politicians' honesty. In other words, citizens deem it necessary to use effective methods at the political level in order to manage the risk correctly. On the other hand, honesty evaluations regarding politicians directly predicted citizens' anxiety about coronavirus, independent of risk perception. It can be interpreted that politicians acting transparently and honestly can be effective in reducing citizens' anxiety, regardless of their risk perception. The coronavirus pandemic, which the whole world is trying to deal with simultaneously, has brought many uncertainties (Douglas, 2020). In this chaotic process, considering there is a lot of misinformation (Mian \& Khan, 2020), and that many people believe in conspiracy theories rather than politicians and authorities (Douglas, 2020; Van Bavel et al., 2020), it can be argued that ensuring accurate and transparent flow of information about the process, and trust in the honesty of the authorities, directly reduces anxiety. At this point, it is seen that while individuals' belief that the process is not managed effectively (competence) triggers anxiety through increased risk perception, their belief that something is hidden from them or that they cannot access correct information (honesty) directly triggers anxiety, regardless of risk perception. In addition to anxiety, the honesty of politicians is also associated with the public's support of preventive health behaviors related to the pandemic and it is emphasized that lack of information and uncertainty lead to believing in conspiracy theories and antipreventive behaviors (Douglas, 2020). It seems possible when people believe that they have access to the accurate information, preventive health behaviors increase, which may decrease their anxiety. Therefore, honesty of politicians is also important to reinforce public's preventive health behaviors related to the pandemic.

When the findings considered in terms of the predictors of psychological well-being and helping behavior at individual level resources, it was found that increase in self-confident style, increase in seeking of social support and decrease in helpless style predicted helping behavior through psychological well-being. Submissive and optimistic styles did not predict helping behavior. Seeking of social support and selfconfident styles are considered as active ways to cope with stress (Hisli-Şahin \& Durak, 1995). The findings showed that people who cope actively and effectively with stress, felt better in the coronavirus pandemic, and this improvement in the psychological well-being, in turn, associated with being more responsible for others' well-being and acting more prosocial. In a recent study (Van Bavel et al., 2020) it was emphasized that the exchange of online social support between people during the coronavirus pandemic could improve their psychological resilience. It seems that both receiving social support and providing social support for others have positive effects on the psychological well-being of people, even in online forms. The finding of this study regarding the relationship between having functional relationships, getting social 
support and psychological well-being is supported. (Diener \& Tay, 2017; Doğan, 2006; Dunn et al. 2014; Siewert et al., 2011). Helping behavior requires not only the ability to distinguish between right and wrong on moral ground (moral reasoning), but also the maturity of taking responsibility for one's own actions (Hardy \& Carlo, 2011). It seems reasonable that people with a high sense of responsibility who use active and effective ways to cope with stress feel better during life crises and as a result, are more engaged in helping behavior. According to the findings regarding the relationships between passive ways to cope with stress and helping behavior through psychological well-being, helpless style predicted well-being and helping behavior, but submissive style did not. It is known that the helpless style is much more closely related to experiencing problems in many domains, such as family problems, interpersonal communication problems, and health problems compared to the submissive style (Hisli-Şahin \& Durak, 1995). Those who predominantly try to cope with their own problems will have lower well-being and it is unrealistic to expect these people to engage in helping behavior. Therefore, in the light of the literature it is comprehensible that the decrease in helpless coping style explained wellbeing and helping behavior, but the submissive coping style did not.

When findings examined in terms of the relationship between political trust handled as a national level resource in this study, and helping behavior, it was found that psychological well-being has a mediating role in this relationship. The expectation dimension, which means "citizens' being satisfied with the actions of politicians in the country and the beliefs that politicians will act beneficially for everyone in the country" positively predicted helping behaviour through psychological well-being. Based on this finding, it can be concluded that satisfaction with the actions of politicians increases the cooperation among citizens via improvement in the citizens' psychological well-being, while the opposite situation leads to a decrease in individuals' well-being and prosocial behavior. As Van Bavel et al. (2020) pointed out in their review, it is likely that prosocial behavior of individuals will increase as respected politicians and leaders display examples of prosocial behavior regarding the pandemic. For this reason, it is important to build trust so that politicians are perceived as respected by citizens. The findings of this study provide empirical evidence that the expectation dimension of political trust, namely the belief that politicians work for the benefit of the public, may be important for the public's prosocial behavior. Destructive effects of the pandemic can be curbed by strengthening the citizens' sensitivity to care for others. So, they can be encouraged to take preventive health behaviors not only for themselves but also for others. People comply with the norms and cooperate when they believe that the politicians' motivation in their activities is based on public interest rather than their own interest. Thus, it is crucial for the public health that politicians strengthen their work for the benefit of the public and fulfill the needs and expectations of all groups in the society. When citizens perceive an uncontrollable threat such as war or terrorism in their country, their response to this threat is often in the form of an increase in political trust, which is called the rally effect (Dinesen \& Jæger, 2013). In a study conducted in Sweden, it was found that the COVID-19 pandemic was perceived by the public as a war-like threat and that the citizens' level of political trust increased after this crisis (Esaiasson et al., 2020). In the presence of this threat, strengthening democratic practices may lead to an increase in citizens' trust in politicians and, consequently, in both their psychological well-being and their prosocial behaviors. At this point, beyond taking effective actions of politicians to mitigating the negative effects of pandemic (competency), there are additional duties for them such as defending the interests of all citizens by fulfilling public's needs (expectation) and being honest and transparent about the process (honesty). In coping with large-scale long-term health crises, individuals need resources at national level in addition to their ability to cope with stress.

In this study, individual and national level resources and some factors related to these resources that can be functional during the pandemic that threatens modern age people regardless of geography, race, culture or gender are revealed. All in all, this research shows the factors that affect Turkish citizens' response (anxiety and prosocial behaviours) to COVID-19 pandemic. Besides, it contributes to literature by revealing the importance of coping styles, political trust, psychological well-being and perceived risk in the crisis of COVID-19. This study is one of the few studies focusing on both individual and national level resources about COVID-19 conducted in Turkey.

Despite these contributions to the literature, this study has several limitations. In a period when physical isolation was essential, data was collected via online platforms with selfreport measurement tools. Although this is seen as one of the limitations of the study, it was thought that collecting the data via online platforms in a period that almost everyone has started online life might have increased the willingness of the participants to join this research. Considering that the political and social issues in the study were measured with self-report questionnaires, the possibility of participants to be affected by social desirability is another limitation of the study. Additionally, the changes in people during the process were not examined in this study, since the measurement was taken only once. Future studies can focus on the question whether the level of political trust, helping behavior, risk perception and psychological well-being in people change during this process. Although it is not addressed in this study, it is thought that the ambiguity of when the pandemic will end and people's expectations for the future may affect their well-being, helping behaviors and political trust. Therefore, conducting 
new studies including the variables such as perception of uncertainty and future expectations will provide important contributions to the literature regarding the effects of COVID-19 on social life.

Acknowledgements We would like to thank Dr. İrem Akıncı for her comments on the manuscript.

Availability of Data and Material The datasets generated during and/or analysed during the current study are available from the corresponding author on reasonable request.

Author Contributions All authors contributed to the study conception, design, material preparation and data collection. Analysis was performed by [Özge Ünal], [Hilal Kaya]. The first draft of the manuscript was written by [Özge Ünal], [Merve Cesur-Atintaş] and all authors commented on previous versions of the manuscript. All authors read and approved the final manuscript.

\section{Declarations}

Ethics Approval All procedures performed in studies involving human participants were in accordance with the ethical standards of the institutional and/or national research committee and with the 1964 Helsinki declaration and its later amendments or comparable ethical standards.

Consent to Participate Informed Consent was obtained from all individual participants included in the study.

Conflict of Interest This article involves no conflict of interest.

\section{References}

Allcott, H., Braghieri, L., Eichmeyer, S., \& Gentzkow, M. (2020). The welfare effects of social media. American Economic Review, 110, 629-676. https://doi.org/10.1257/aer.20190658.

Alper, S., Bayrak, F., \& Y1lmaz, O. (2020). Psychological correlates of COVID-19 conspiracy beliefs and preventive measures: Evidence from Turkey. Current Psychology, https://doi.org/10.1007/s12144020-00903-0.

Balaratnasingam, S., \& Janca, A. (2006). Mass hysteria revisited. Current Opinion in Psychiatry, 19, 171-174. https://doi.org/10.1097/01.yco. $0000214343.59872 .7 \mathrm{a}$.

Bronfman, N. C., Cisternas, P. C., López-Vázquez, E., \& Cifuentes, L. A. (2016). Trust and risk perception of natural hazards: Implications for risk preparedness in Chile. Natural Hazards, 81(1), 307-327.

Brooks, S. K., Webster, R. K., Smith, L. E., Woodland, L., Wessely, S., Greenberg, N., \& Rubin, G. J. (2020). The psychological impact of quarantine and how to reduce it: Rapid review of the evidence. The Lancet, 395(10227), 912-920.

Cabarkapa, S., Nadjidai, S. E., Murgier, J., \& Ng, C. H. (2020). The psychological impact of COVID-19 and other viral epidemics on frontline healthcare workers and ways to address it: A rapid systematic review. Brain, behavior, \& immunity-health, 8(100144), 1-10.

Çoymak, A. (2009). Association of religious identification, secular identification, perceived discrimination, and political trust with ethnic and societal (national) identification. (Unpublished master's thesis). Middle East Technical University.

Diener, E., \& Tay, L. (2017). A scientific review of the remarkable benefits of happiness for successful and healthy living. In Happiness transforming the development landscape, (pp. 90-117). The Centre for Bhutan Studies and GNH.

Diener, E., Wirtz, D., Tov, W., Kim-Prieto, C., Choi, D. W., Oishi, S., \& Biswas-Diener, R. (2010). New well-being measures: Short scales to assess flourishing and positive and negative feelings. Social Indicators Research, 97(2), 143-156.

Dinesen, P. T., \& Jæger, M. M. (2013). The effect of terror on institutional trust: New evidence from the 3/11 Madrid terrorist attack. Political Psychology, 34(6), 917-926.

Doğan, T. (2006). Üniversite öğrencilerinin iyilik halinin incelenmesi. Hacettepe Üniversitesi Ë̈itim Fakültesi Dergisi, 30(30), 120-129.

Douglas, K. (2020). COVID-19 conspiracy theories. Group Processes and Intergroup Relations. Retrieved from https://www. researchgate.net/publication/346395248_COVID-19_conspiracy_ theories

Dunn, E. W., Aknin, L. B., \& Norton, M. I. (2014). Prosocial spending and happiness: Using money to benefit others pays off. Current Directions in Psychological Science, 23(1), 41-47.

Esaiasson, P., Sohlberg, J., Ghersetti, M., \& Johansson, B. (2020) How the coronavirus crisis affects citizen trust in institutions and in unknown others-evidence from "the Swedish experiment". European Journal of Political Research, Retrieved from https://doi.org/10. 1111/1475-6765.12419.

Folkman, S., \& Lazarus, R. S. (1980). An analysis of coping in a middleaged community sample. Journal of Health and Social Behavior, 21(3), 219-239. https://doi.org/10.2307/2136617.

Forgas, J. P., Dunn, E., \& Granland, S. (2008). Are you being served ... ? An unobtrusive experiment of affective influences on helping in a department store. European Journal of Social Psychology, 38, 333 342.

Fransen, K., Haslam, S. A., Steffens, N. K., Vanbeselaere, N., De Cuyper, B., \& Boen, F. (2015). Believing in "us": Exploring leaders' capacity to enhance team confidence and performance by building a sense of shared social identity. Journal of Experimental Psychology: Applied, 21(1), 89-100.

Hardy, S. A., \& Carlo, G. (2011). Moral identity: What is it, how does it develop, and is it linked to moral action? Child Development Perspectives, 5(3), 212-218.

Hisli-Şahin, N., \& Durak, A. (1995). Üniversite Öğrencileri için bir stresle bașa çıkma tarzı ölçeği. Türk Psikoloji Dergisi, 10(34), 56 73.

Horesh, D., Kapel Lev-Ari, R., \& Hasson-Ohayon, I. (2020). Risk factors for psychological distress during the COVID-19 pandemic in Israel: Loneliness, age, gender, and health status play an important role. British Journal of Health Psychology, 25(4), 925-933.

Jöreskog, K. G., \& Sörbom, D. (1993). LISREL 8 User's reference guide. Scientific Software International.

Lades, L., Laffan, K., Daly, M., \& Delaney, L. (2020). Daily emotional well-being during the COVID-19 pandemic. British Journal of Health Psychology, 25, 902-911. https://doi.org/10.1111/bjhp. 12450.

Lyubomirsky, S., \& Dickerhoof, R. (2011). A construal approach to increasing happiness. In J. E. Maddux \& J. P. Tangney (Eds.), Social psychological foundations of clinical psychology (pp. 229244). The Guilford Press.

Mana, A., \& Sagy, S. (2020). Brief report: Can political orientation explain mental health in the time of a global pandemic? Voting patterns, personal and National Coping Resources, and mental health during the coronavirus crisis. Journal of Social and Clinical Psychology, 39(3), 165-171.

Marinthe, G., Brown, G., Delouvée, S., \& Jolley, D. (2020). Looking out for myself: Exploring the relationship between conspiracy mentality, perceived personal risk and COVID-19 prevention measures. British Journal of Health Psychology, 25, 957-980. 
Martela, F., \& Ryan, R. M. (2016). Prosocial behavior increases wellbeing and vitality even without contact with the beneficiary: Causal and behavioral evidence. Motivation and Emotion, 40, 351-357.

Mian, A., \& Khan, S. (2020). Coronavirus: The spread of misinformation. BMC Medicine, 18(1), 1-2.

Morgeson, F. P., Mitchell, T. R., \& Liu, D. (2015). Event system theory: An event-oriented approach to the organizational sciences. Academy of Management Review, 40(4), 515-537.

Paolini, D., Maricchiolo, F., Pacilli, M.G. et al. (2020) COVID-19 lockdown in Italy: The role of social identification and social and political trust on well-being and distress. Current Psychology. https://doi. org/10.1007/s12144-020-01141-0.

Philip, J., \& Cherian, V. (2020). Factors affecting the psychological wellbeing of health care workers during an epidemic: A thematic review. Indian Journal of Psychological Medicine, 42(4), 323-333.

Pidgeon, N. F., Lorenzoni, I., \& Poortinga, W. (2008). Climate change or nuclear power-No thanks! A quantitative study of public perceptions and risk framing in Britain. Global Environmental Change, $18(1), 69-85$.

Piliavin, J. A. (2003). Doing well by doing good: Benefits for the benefactor. In C. L. M. Keyes \& J. Haidt (Eds.), Flourishing: Positive psychology and the life well-lived (p. 227-247). American Psychological Association.

Poortinga, W., \& Pidgeon, N. F. (2005). Trust in risk regulation: Cause or consequence of the acceptability of GM food? Risk Analysis: An International Journal, 25(1), 199-209.

Reicher, S., Haslam, S. A., \& Hopkins, N. (2005). Social identity and the dynamics of leadership: Leaders and followers as collaborative agents in the transformation of social reality. The Leadership Quarterly, 16(4), 547-568.

Salovey, P., Mayer, J. D., \& Rosenhan, D. L. (1991). Mood and healing: Mood as a motivator of helping and helping as a regulator of mood. In M. S. Clark (Ed.), Prosocial behavior. Sage.
Schwartz, C. E., Keyl, P. M., Marcum, J. P., \& Bode, R. (2009). Helping others shows differential benefits on health and well-being for male and female teens. Journal of Happiness Studies, 10(4), 431-448.

Siewert, K., Antoniw, K., Kubiak, T., \& Weber, H. (2011). The more the better? The relationship between mismatches in social support and subjective well-being in daily life. Journal of Health Psychology, 16(4), 621-631.

Silva, J. L., Marks, L. D., \& Cherry, K. E. (2009). The psychology behind helping and prosocial behaviors: An examination from intention to action. In Lifespan Perspectives on Natural Disasters (pp. 219 240). Springer.

Stanko, K. E., Cherry, K. E., Ryker, K. S., Mughal, F., Marks, L. D., Brown, J. S., et al. (2015). Looking for the silver lining: Benefit finding after hurricanes Katrina and Rita in middle-aged, older, and oldest-old adults. Current Psychology, 34(3), 564-575.

Taha, S., Matheson, K., Cronin, T., \& Anisman, H. (2014). Intolerance of uncertainty, appraisals, coping, and anxiety: The case of the $2009 \mathrm{H}$ $1 \mathrm{~N} 1$ pandemic. British Journal of Health Psychology, 19(3), 592605.

Telef, B. B. (2013). Psikolojik iyi oluş ölçeği: Türkçeye uyarlama, geçerlik ve güvenirlik çalıșması. Hacettepe Üniversitesi Ĕ̆itim Fakültesi Dergisi, 28(28-3), 374-384.

Van Bavel, J. J., Baicker, K., Boggio, P. S., Capraro, V., Cichocka, A., Cikara, M., et al. (2020). Using social and behavioural science to support COVID-19 pandemic response. Nature Human Behaviour, $1-12$.

World Health Organization (WHO) (2020). Coronavirus disease (COVID-2019) situation reports. Geneva: WHO. [Accessed Mar 2020]. Available from: https://www.who.int/emergencies/diseases/ novel-coronavirus-2019/situation-reports

Publisher's Note Springer Nature remains neutral with regard to jurisdictional claims in published maps and institutional affiliations. 